\title{
Conflict between human and wild Sumatran Elephant (Elephas maximus sumatranus Temminck, 1847) in Aceh Province, Indonesia
}

\author{
INDIRA NURUL QOMARIAH ${ }^{1, \boldsymbol{v}}$, TUTIA RAHMI ${ }^{2, v v}$, ZURAIDAH SAID $^{1}$, ARIEF WIJAYA ${ }^{1}$ \\ ${ }^{1}$ World Resources Institute Indonesia. Wisma PMI Lantai 7, Jl. Wijaya I No. 63, Kebayoran Baru, South Jakarta 12110, Jakarta, Indonesia. \\ Tel./fax.+62-81234-267140, ”email: indiranurulq@gmail.com \\ ${ }^{2}$ Biodiversity Conservation Agency (BKSDA) Aceh. Jalan Cut Nyak Dhin KM 1,22, Banda Aceh 23232, Aceh, Indonesia. \\ Tel.: +62- 651-42694, "`email: tutiarahmi05@gmail.com
}

Manuscript received: 24 October 2018. Revision accepted: 2 December 2019.

\begin{abstract}
Qomariah IN, Rahmi T, Said Z, Wijaya A. 2019. Conflict between human and wild Sumatran Elephant (Elephas maximus sumatranus Temminck, 1847) in Aceh Province, Indonesia. Biodiversitas 20: 77-84. Aceh Province has the largest habitat for Sumatran elephant. However, the elephant population in the province keeps decreasing due to frequent conflict with humans. This study aimed to observe the trend and pattern of Human-elephant Conflict (HEC) in Aceh, as well as the main causes driving the conflict. To collect information, we carried out desk study, secondary data collection, and interviews with relevant actors in Aceh Jaya, Pidie, and Aceh Timur District. We collected data of HEC during the 2012-2017 period in 16 districts across Aceh. The result shows that during the six years, there were 262 HEC cases occurred in Aceh, where Aceh Timur and Aceh Jaya contributed the highest number of HEC incidence, with 47 and 44 cases respectively. Maximum Entropy analysis shows that the main factor causing the conflict is "Distance from the human settlement" with $84.7 \%$ contribution, followed by "Primary forest loss" $(14.1 \%$ contribution $)$. From the findings, we suggest reforestation in areas that becomes elephant home range and creation of barriers within the conservation forest boundaries. Moreover, HEC mitigation action should also be incorporated in provincial spatial planning (Rencana Tata Ruang Wilayah - Provinsi) to minimize further economic loss and wildlife extinction.
\end{abstract}

Keywords: Conservation, Elephas maximus sumatranus, human-elephant conflict, sumatran elephant

Abbreviations: HEC: Human-elephant Conflict, CRU: Conservation Response Unit, BKSDA: Biodiversity Conservation Agency

\section{INTRODUCTION}

The Sumatran Elephant (Elephas maximus sumatranus) is a sub-species of Asian elephant endemic to the Island of Sumatra, Indonesia. Elephant plays an essential role in preserving forest and ecosystems (Perera 2009). During the dry season, elephants help to suffice the water needs of almost all living things in their habitat, by digging up the soils for water using their ivory. Elephants like eating large grasses that stimulate the growth of softer grass, the diets for deer and muntjac (Santiapillai and Ramono 1990; Gopala et al. 2011).

As a wide-home-range animal, elephants help spread seeds when it moves to search for food and water. This causes the growth of new trees. When moving around the forest, elephants cause tree branches, fruits, flowers, seeds, and leaves to fall to the ground, its large body causes an open path allowing the fallen fruits, flowers, seeds, and leaves available for other animals, such as monkeys and civets, to eat (Campos-Arceiz and Blake 2011). Sumatran elephants are acknowledged as umbrella species in Gunung Leuser National Park, acting as an indicator for wildlife conservation management (Kuswanda and Barus 2017). Population decline of elephant can lead to adverse impacts on the whole complexity of the forest ecosystem.

The high rate of elephant death will reduce the population of this species, which is now categorized as critically endangered by The International Union for Conservation of Nature or IUCN (Gopala et al. 2011). In the 1980s, the population of Sumatran elephants has estimated 2,800-4,800 individuals. This number dropped dramatically by $35 \%$ to 2,400-2,800 individuals in 2007 and dropped again to 1,724 individuals in 2014 (Santiapillai and Ramono 1990; Directorate General of Forest Protection and Nature Conservation 2007; Grehenson 2015). Human-elephant Conflict (HEC) is considered as the most significant threat to the elephant population in Sumatra (Hedges et al. 2005; Azmi and Gunaryadi 2011). In Aceh Province, it is estimated that there were 600-850 individuals in 1985 and currently, there are only 500 elephants left (Blouch and Simbolon 1985; Keumala 2018).

There are several types of Human-elephant Conflicts, among others: crops trampling, crops raiding, physical attack on buildings and human, and retaliatory killing. The human does retaliatory killing to anticipate past HEC from happening again (Acharya et al. 2016; Inskip and Zimmermann 2009). This killing attempt includes the spreading of toxic substances, installation of high-voltage electrical wires, and the placement of snares for elephant death purpose. Human-elephant Conflict (HEC) is defined as human-elephant interaction leading to a destructive result, to humans/elephants themselves or to human's space of interest. An appearance of an elephant in plantation area 
or human settlement, which does not cause any damage is not categorized as conflict.

Currently, of about $85 \%$ of elephants habitat in Sumatra and Kalimantan live outside conservation areas (Directorate General of Forest Protection and Nature Conservation 2007). Elephants habitat require minimum areas of $97 \mathrm{~km}^{2}$ for their living home range (Zoological Society of London 2011). A herd of elephants will create damage to cultivated crops and agriculture lands, once these areas overlap with their home range. In general, HEC occurs inside elephants habitat that is converted to human settlements or agriculture lands (Azmi and Gunaryadi 2011; Gunaryadi et al. 2017).

This study aimed to observe the trend and pattern of Human-elephant Conflict (HEC) in Aceh, as well as the main drivers of the conflict. The result of this study is useful as a reference to design conservation strategy to avoid Human-elephant Conflict in Aceh Province, as well as to support sustainable development plan at the provincial level through better spatial planning.

\section{MATERIALS AND METHODS}

\section{Study area}

The study area encompasses Aceh Province (Figure 1), situated in 94 ${ }^{\circ} 57^{\prime} 57.6^{\prime \prime} \mathrm{E}-98^{\circ} 17^{\prime} 13.2^{\prime \prime} \mathrm{E}$ and $01^{\circ} 58^{\prime} 37.2^{\prime \prime} \mathrm{N}$ $06^{\circ} 04^{\prime} 33.6^{\prime \prime} \mathrm{N}$. Aceh Province is located at the northern part of Sumatra, Indonesia. Aceh has 18 districts and five cities, with an average altitude of 125 masl. The forest land reaches 2,270,080 ha or covers $40 \%$ of its entire land area (Central Bureau of Statistics of Aceh Province 2017a). The forest ecosystem has a large area of intact lowland and montane rainforest, especially in the Leuser Ecosystem. Dipterocarp is the most dominant vegetation with patches of pine forest (Rood et al. 2008). We were focus on the 16 districts that experienced HEC i.e. Aceh Jaya, Aceh Barat, Aceh Besar, Pidie, Pidie Jaya, Bireuen, Aceh Utara, Aceh Timur, Bener Meriah, Gayo Lues, Aceh Tengah, Subulussalam, Aceh Tamiang, Aceh Tenggara, Aceh Selatan, and Nagan Raya (grey highlighted in Figure 1).

\section{Procedures}

Data collection

Data collection and interview were carried out from January to April 2018. The HEC data from 2012 to 2017 were compiled from Biodiversity Conservation Agency (Badan Konservasi Sumberdaya Alam or BKSDA) in Aceh Province, and Gunung Leuser National Park Agency (Balai Besar Taman Nasional Gunung Leuser or BB-TNGL). Additional secondary HEC data were also collected from various Indonesia newspaper and media. Deforestation data were generated from Global Forest Watch (https://www.globalforestwatch.org/) using Tree Cover Loss estimate within the primary forest in Aceh Province during the 2001-2016 period, and the data were accessed on February $27^{\text {th }}, 2018$. Primary forest area was generated using the Ministry of Environment and Forestry land cover data from 2000 (23 land cover categories, comprising of 6 forest classes). Tree Cover Loss data outside the Primary Forest were excluded from the analysis. We used 2016 data of settlements and roads, collected from Indonesian Geospatial Information Agency (Badan Informasi Geospasial or BIG) to map HEC incidence and risks.

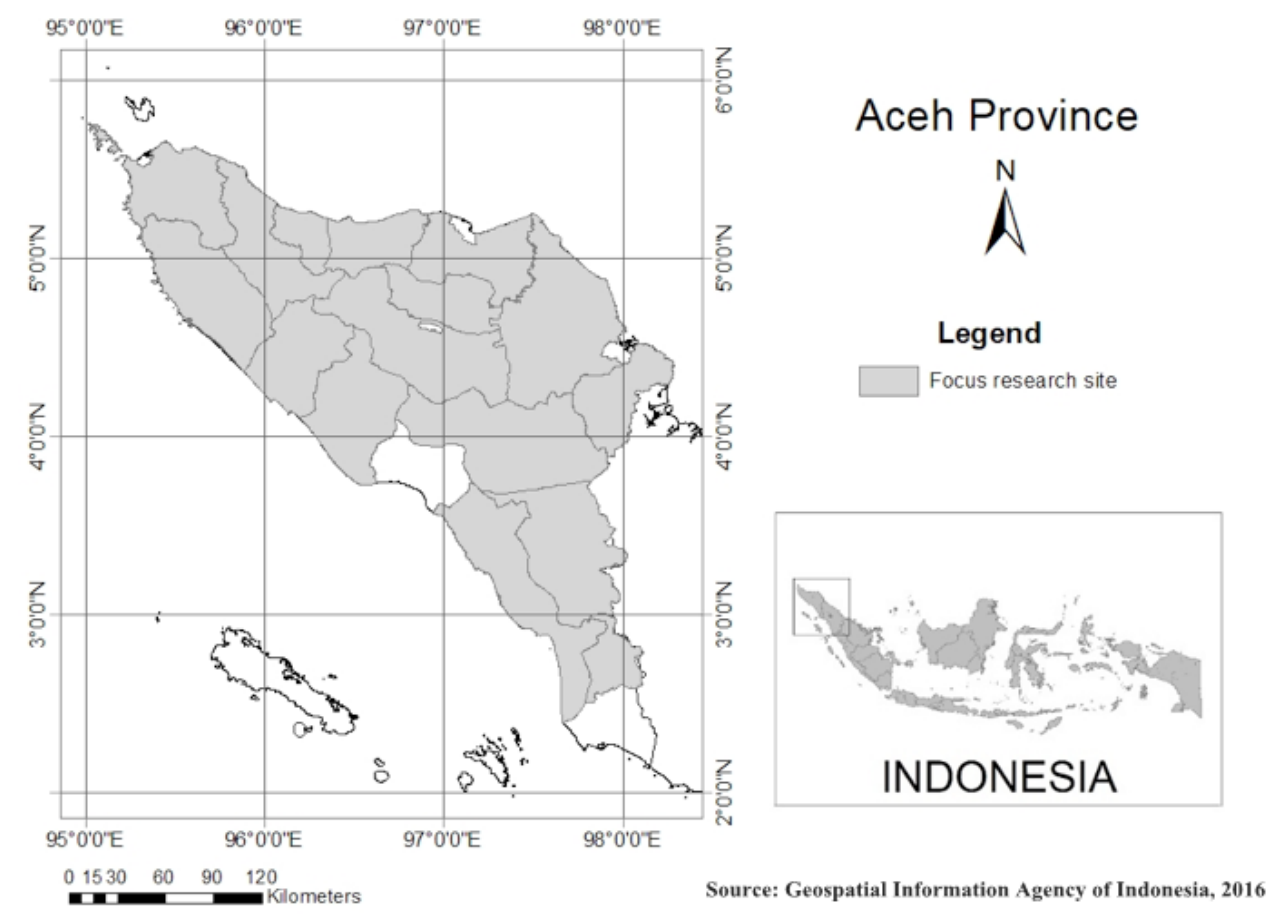

Figure 1. Location of 16 districts under study in Aceh Province in Sumatra Island, Indonesia 
Table 1. The matrix of variables used in assessing risk level of human-elephant conflict.

\begin{tabular}{|c|c|c|c|c|}
\hline $\begin{array}{l}\text { Conflict } \\
\text { intensity }\end{array}$ & $\begin{array}{c}\text { Attacked } \\
\text { plantation } \\
\text { area }\end{array}$ & $\begin{array}{l}\text { Attacked } \\
\text { building }\end{array}$ & $\begin{array}{l}\text { Elephant } \\
\text { casualties }\end{array}$ & $\begin{array}{c}\text { Human } \\
\text { casualties }\end{array}$ \\
\hline $\begin{array}{c}{[0]} \\
\text { Elephants } \\
\text { appearance }\end{array}$ & $\begin{array}{c}{[0]} \\
\text { None }\end{array}$ & $\begin{array}{c}{[0]} \\
\text { None }\end{array}$ & $\begin{array}{c}{[0]} \\
\text { None }\end{array}$ & $\begin{array}{c}{[0]} \\
\text { None }\end{array}$ \\
\hline $\begin{array}{c}{[1]} \\
<1 \text { week }\end{array}$ & $\begin{array}{c}{[1]} \\
<10 \\
\text { hectares }\end{array}$ & $\begin{array}{c}{[1]} \\
\text { One } \\
\text { hut/house } \\
\text { attacked }\end{array}$ & $\begin{array}{c}{[1]} \\
\text { Elephant } \\
\text { was injured } \\
\text { or separated } \\
\text { from the } \\
\text { herd }\end{array}$ & $\begin{array}{c}{[1]} \\
\text { Human was } \\
\text { chased }\end{array}$ \\
\hline $\begin{array}{c}{[2]} \\
1 \text { to } 3 \\
\text { weeks }\end{array}$ & $\begin{array}{c}{[2]} \\
10-100 \\
\text { hectares }\end{array}$ & $\begin{array}{c}{[2]} \\
2-5 \\
\text { huts/houses } \\
\text { attacked }\end{array}$ & $\begin{array}{c}{[2]} \\
\text { An elephant } \\
\text { died }\end{array}$ & $\begin{array}{c}{[2]} \\
\text { Human was } \\
\text { injured (not } \\
\text { severe) }\end{array}$ \\
\hline $\begin{array}{c}{[3]} \\
>1 \text { month }\end{array}$ & $\begin{array}{c}{[3]} \\
>100 \\
\text { hectares }\end{array}$ & $\begin{array}{c}{[3]} \\
\text { More than } 5 \\
\text { huts/houses } \\
\text { attacked }\end{array}$ & $\begin{array}{c}{[3]} \\
\text { More than } \\
\text { one } \\
\text { elephant } \\
\text { died }\end{array}$ & $\begin{array}{c}{[3]} \\
\text { Human was } \\
\text { severely } \\
\text { injured or } \\
\text { died }\end{array}$ \\
\hline
\end{tabular}

Note: There are five variables used to asses Risk Level of each HEC, each of the variables scores from 0 (the lowest risk) to 3 (the highest risk). The variables assessed were: 1. Conflict Intensity, which describes the length of an HEC incidence, 0 means elephants were seen but did nothing lead to conflict, 3 means the HEC occurred for more than a month; 2. Attacked plantation area, which refers to total plantation area destroyed by elephants; 3. Attacked building, which represents the number of building attacked by elephants; 4 . Elephant Casualties, which describes the elephant level of injury/death caused by HEC, 0 means no injury and no death resulted, while 3 means that there was more than one elephant death toll; 5. Human Casualties, which describes human level of injury/death caused by HEC, 0 means no injury and no death, while 3 means HEC caused severe injuries or death to human.

To get reliable and unbiased information on how the HEC occurred, as well as the existing mitigation efforts to avoid the conflicts, we undertook in-depth interviews in the districts of Aceh Jaya, Pidie, and Aceh Timur. The key persons interviewed were from BKSDA Aceh, Conservation Response Unit (CRU) Aceh Jaya, CRU Pidie, CRU Aceh Timur, BB-TNGL, and Wildlife Response Unit (WRU) Aceh Timur. Interviews with communities experiencing HEC in the past were carried out to collect information on land use change history, economic losses resulted, crop-raiding occurred, and types of commodities destroyed by elephants. Total of interviewed respondents were 61 people, consist of 12 staff of Ministry of Environment and Forestry, five heads of village (kepala kampung), 41 farmers, and three Non-Government Organizations staff. The interviews were done in villages: Masen, Cot Punti, Krueng Ayun, and Ie Jeureungeh, located in Aceh Jaya District; Krueng Lala and Tuha Lala in Pidie District; and Bunin, SP1, Seumanah Jaya, Punti Payung, and Jambo Reuhat in Aceh Timur District. These villages were located in adjacent to forest areas and had experienced elephant disruption in the cultivated plantation close to the villages.

\section{Data analysis}

All spatial data (deforestation, settlements, and roads) were analyzed in ArcGIS 10.5.1, while data of HECs and collected from the interviews were analyzed in Microsoft Excel 2016. Analysis of the trend was based on the frequency of HEC incidence and risk level of the conflict. The risk level of conflict was assessed based on criteria that were modified from criteria listed in Ministerial Decree number 48/2008 or PERMENHUT No. 48/2008 (Directorate General of Forest Protection and Nature Conservation 2008) and Inskip and Zimmermann (2009). The risk level of each HEC was calculated based on the following formula:

Risk level of HEC $=$ Point of Conflict Intensity + Point of Attacked Plantation Area + Point of Attacked Building + Point of Elephant Casualties + Point of Human Casualties

Analysis of HEC Pattern was done in Microsoft Excel 2016, based on spatial and temporal distribution. Analysis of conflict-driving factors was done in Maximum Entropy (MaxEnt) software 3.4.1 version. Maxent modeling has the great prediction for identifying distributions and wildlife habitat from incomplete data. The Maxent algorithm only needs presence data to converge the probability distribution and estimates the predicted distribution in the sampling area to the whole background location. Maxent analysis is a very useful tool for wildlife research and management because absence data is often unavailable and difficult to verify (Baldwin 2009). Maxent analysis also predicts the percent distribution of each variable influence the HEC occurrence, so the result will provide information of which variables have the highest influence on the HEC. We used three variables to analyze conflict-driving factor of HEC, i.e., distance from human settlement, distance from the road, and primary forest loss. Distance from human settlement and distance from road were assessed by Euclidean Distance. Primary forest loss data was calculated from Tree Cover Loss (TCL) data in the primary forest area.

\section{RESULTS AND DISCUSSION}

\section{Trend and pattern of Human-elephant Conflict}

Our data show that during 2012-2017, there were 262 cases of HEC in Aceh resulting in 11 people injured and eight death tolls. Within the same period, there were 68 elephants died, all of which were resulted from three different causes: 45 (66\%) were died by HEC, 14 (21\%) were by poaching, and nine $(13 \%)$ were by natural causes (Figure 2). When an elephant was found dead inside a forest or found dead without its ivory, then it was categorized as death by poaching. When an elephant died due to illness, old age, or falling from a cliff, it was categorized as death by natural cause. Within all the 
elephants died by HEC, 26 individuals (58\%) were poisoned, eight $(18 \%)$ were electrocuted in high-voltage electrical wires, three $(7 \%)$ were snared, one $(2 \%)$ was stabbed with a spear, and seven (16\%) were found as skeletons or died for an unknown reason. The collected data were from all death incidences reported. Thus, it is possible that the death cases were higher than the number we collected. The unreported death case of the elephant was because the communities did not know where to report any elephant death incidence.

The trend of HEC in Aceh had increased over the study period. In 2017, there were 96 cases of HEC, which was equal to $228 \%$ of the previous year. In contrast to this finding, the number of HEC cases during the study period had slightly declined compared to the same number during 2000-2006, which reached to 316 cases (Rood et al. 2008). Based on the risk level of HEC, the extent of damage caused by HEC was declining in 2016, which turned to raise in 2017 (Figure 3). The trend line of risk level showed that HEC in Aceh tends to be more vulnerable and dangerous, both for the local community and for the wild elephants involved in the conflict.

Cases of HEC were found in 16 districts in Aceh Province. Districts with the highest number of HEC include Aceh Timur, Aceh Jaya, and Pidie contributing to 47, 44 and 33 of cases, respectively (Figure 4). The most common type of conflict was due to the destruction of communities' plantations and residences. The distribution map of HEC is presented in Figure 5.

In general, HEC occurred the whole time of the year, and tend to increase in April, July, and November (Figure 6 ). The months of April and November are normally a transition between rainy and dry season. During this transition period, weather condition tends to be extreme, causing inconsistency in rainfall intensity and temperature fluctuation. This condition potentially causes natural disasters which will urge wildlife, including elephants, to get closer to human settlement, as an effort to prevent from getting hit by landslides and fallen trees.

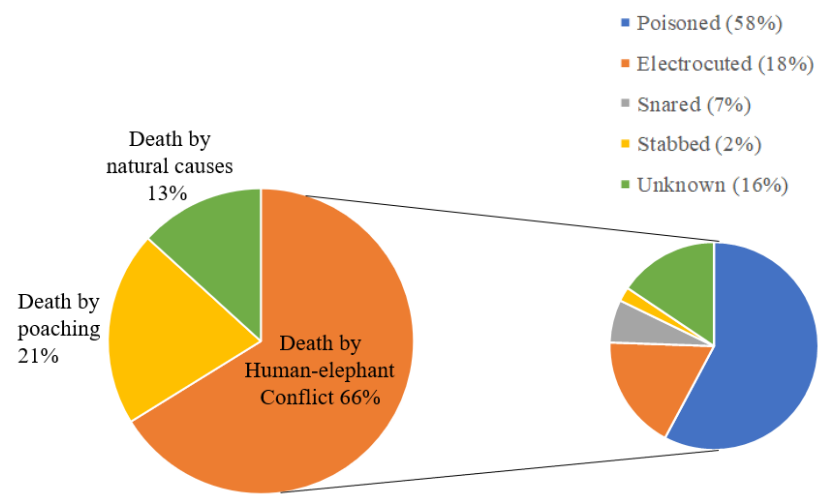

Figure 2. Data of elephant death based on causes (Humanelephant Conflict, poaching, and natural causes). The data were collected from 16 Districts in Aceh Province during the period 2012-2017

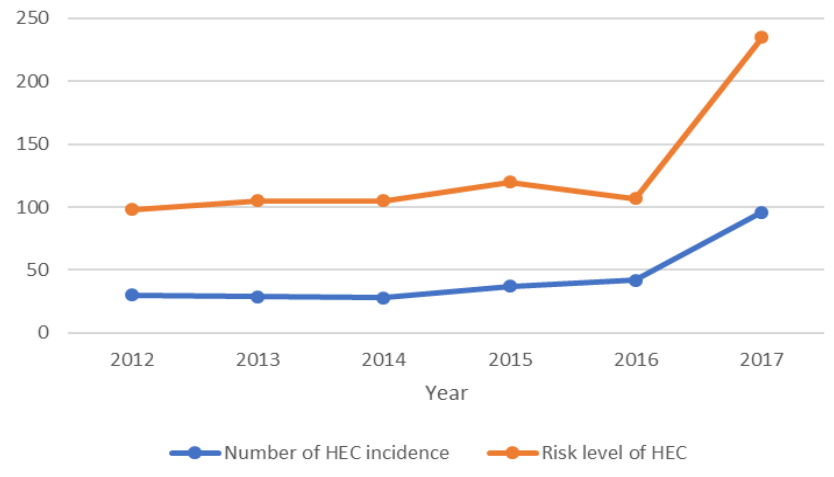

Figure 3. The trend of human-elephant conflict in 16 districts under study in Aceh Province, Indonesia

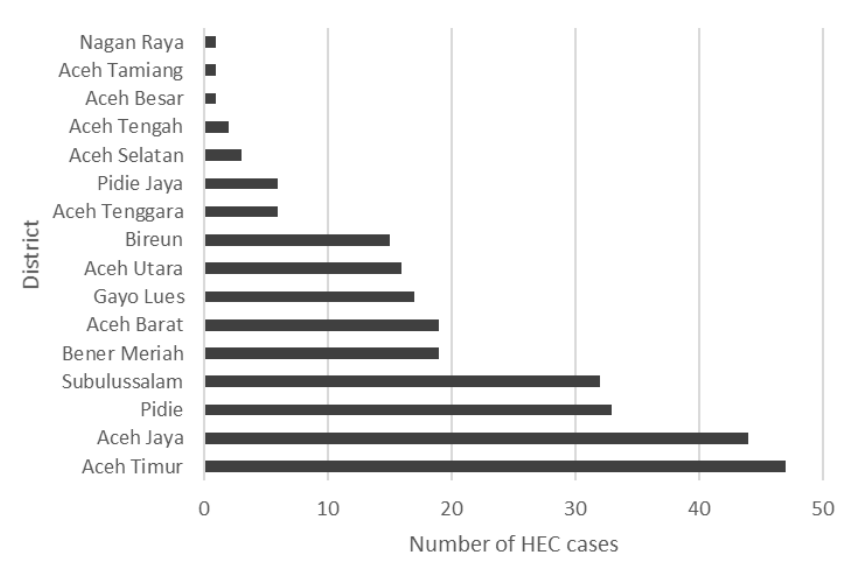

Figure 4. Total number of human-elephant conflict cases in 16 districts of Aceh Province, Indonesia

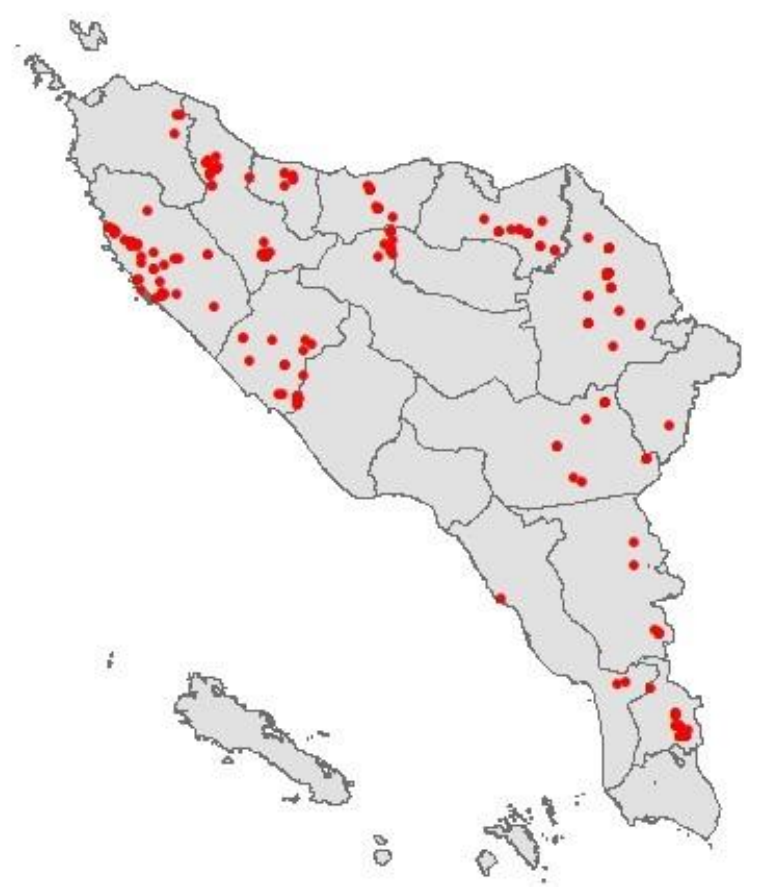

Figure 5.The spatial pattern of human-elephant conflict in 16 District, Aceh Province, Indonesia. Red dots indicate locations where HEC occurred 


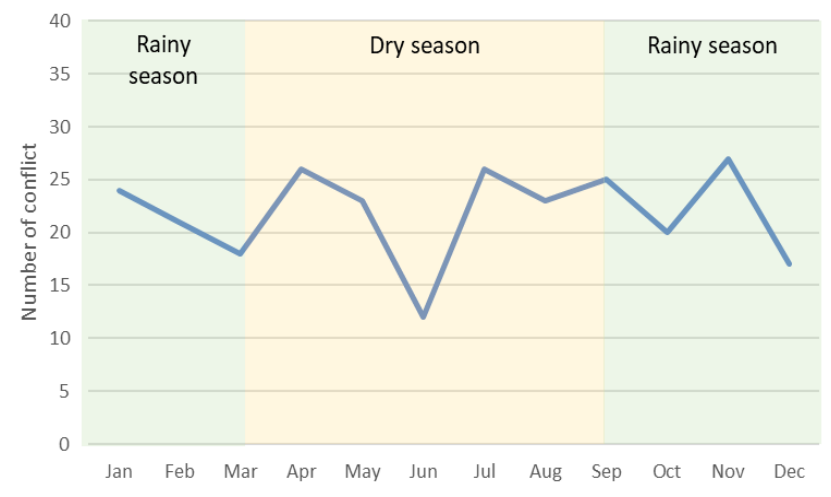

Figure 6. Temporal pattern of Human-elephant Conflict occurrence

\section{Main causes of Human-elephant Conflicts}

In general, deforestation in wildlife habitat will increase the incidence of Human-wildlife Conflicts, which includes human-elephant conflicts. Elephant food stock will be A herd of elephants requires a wide roaming space, as they have a habitual migration behavior to find food, water, and shelter (Nyhus et al. 2000). Since elephants have a strong memory, they can remember their regular walked route. Thus, a herd of elephants will return to the location they have visited before. As human population increases, elephant migration route may be disrupted by human activities, like forest conversion to the plantation. Migration of elephants in this area will trigger Humanelephant conflict. In Assam, India, Human-elephant Conflict increased as $30-40 \%$ forest cover were gone (Chartier et al. 2011). A conversion of 40-50\% forest cover had proved to give negative impact on the population of African elephants (Loxodonta africana) in Sebungwe, Zimbabwe (Hoare and Du Toit 1999).
Road construction in forest areas has contributed to a negative impact on wildlife survival by creating fragmented forest and isolation to wildlife trails. Road construction causes better access for the human to the forest, which results in forest encroachment and conversion to agriculture land, removing wildlife habitat and sources of food. The paved road also induces wildlife death resulted from vehicles hit and poaching, as suggested by Kerley et al. (2002) and Linkie et al. (2006), who observed on Amur tiger (Panthera tigris altaica) in Russia and Eurasian lynx (Lynx lynx) in Germany respectively. In North Sumatra, conflicts between human and Sumatran tiger (Panthera tigris sumatrensis) occurred within 5.6 kilometers buffer from the forest area. Road existence within the buffer area leads to higher risk of tiger death (Wibisono and Pusparini 2010).

decreasing as forest loss increases, and this triggers elephants to find other sources of food in human-cultivated plantations. Studies found that human-elephant conflicts increase as more forests are degraded and converted into non-forest areas (Azmi and Gunaryadi 2011; Chartier et al. 2011; Dublin and Hoare 2004; Sitompul et al. 2010). Monoculture plantations are preferable to elephants as the food source because monoculture plantation encompasses the huge area as food source hotspot which can suffice their feeding needs without having to go far. Cultivated plantations also consist of plants containing more nutrients than natural forest plants (Hoare 2000; Sukumar 2006). Moreover, elephants usually do not only take fruits from cultivated plantation, but they also steal foods from storage in village houses, causing more prominent HEC. Betel nut (Areca catechu or locally known as pinang) and banana (locally known as pisang) are the most common fruits consumed by elephants in Aceh. Types of commodity and parts of plant consumed by elephants are presented in Table 2.

Table 2. List of plants commonly consumed by elephants, from which it leads to crop-raiding and crop-trampling in Aceh

\begin{tabular}{|c|c|c|c|c|c|c|c|c|c|}
\hline \multirow{2}{*}{$\begin{array}{c}\text { Cultivated } \\
\text { plants }\end{array}$} & \multirow{2}{*}{ Local name } & \multicolumn{7}{|c|}{ Part of plants attacked and consumed by elephants } & \multirow{2}{*}{$\begin{array}{c}\text { Attacked in crop- } \\
\text { trampling, not } \\
\text { consumed by elephant }\end{array}$} \\
\hline & & Leaves & Young stems & Old stems & Fruits & Seeds & Midrib & Stem bark & \\
\hline Banana & Pisang & + & + & + & + & & + & & \\
\hline Coconut & Kelapa & & + & & & & + & & \\
\hline Betel nut & Pinang & & + & & & & + & & \\
\hline Oil palm & Kelapa sawit & & + & & & & & & \\
\hline Rice & Padi & & + & + & & + & & & \\
\hline Soybean & Kedelai & & & & & + & & & \\
\hline Chili & Cabai & & & & & & & & + \\
\hline Patchouli & Nilam & & & & & & & & + \\
\hline Jackfruit & Nangka & & & & + & & & + & \\
\hline Cane & Tebu & + & + & + & & & & & \\
\hline Durian & Durian & & & & + & & & + & \\
\hline Peanut & Kacang & & & & & + & & & \\
\hline Rambutan & Rambutan & & & & + & & & + & \\
\hline Rubber & Karet & & & & & & & + & \\
\hline Cacao & Cokelat & & & & & & & & + \\
\hline Corn & Jagung & + & + & + & & + & & & \\
\hline Cempedak & Cempedak & & & & + & & & + & \\
\hline
\end{tabular}


Human population growth has a negative correlation with wild elephant populations (Hoare and Du Toit 1999). Generally, wildlife will intuitively avoid the human encounter. Human presence in the forest will disrupt wildlife' natural life as they release more energy in exploring forest to find places without the human encounter. Consequently, this condition will cause them to have less energy to find partner and breed (Kerley et al. 2002; Primm 1996). Human settlements, which are located too close to wildlife habitat can also trigger a conflict that can be fatal for both human and wildlife (Mattson et al. 1996). The incidence of agriculture land damage caused by elephants increases by the reduction of the distance between human settlement and elephant habitat. Agriculture land located less than one $\mathrm{km}$ from elephant habitat is $60 \%$ more frequent to get attacked by the elephant, while agriculture land located $15 \mathrm{~km}$ from the habitat is $15 \%$ more frequent to get attacked, compared to agriculture lands located farther than $15 \mathrm{~km}$ (Berliani et al. 2016).

We used MaxEnt analysis to predict the causes of Human-elephant conflict (Figure 7). Area Under the Curve (AUC) value was 0.977 meaning that the model has a good or very good prediction ability (Swets 1988). Distribution of areas with potential Human-elephant Conflict is presented in a map (Figure 8), which suggests all over areas of Aceh Province are potential for HEC.

We assessed three driving factors (variables) contributing to HEC, namely: distance from human settlement, primary forest loss, and road distance from the forest area. We assessed the proportion of contribution of each variable to HEC incidence. The result shows that "distance from the human settlement" contributes the highest percentage $(84.7 \%)$ to HEC, followed by primary forest loss (14.1\%) and road distance from the forest (1.2\%). According to the Central Bureau of Statistics of Aceh Province (2017b), Aceh's population increased by $49 \%$ in 26 years from 3.42 million in 1990 to 5.10 million in 2016. Population growth in Aceh resulted in settlement expansion, encroaching forest area. Population rise also led to an increase in basic needs. Hence more agricultural land and plantation were created. It had caused more anthropogenic activities occurred in areas close to the forest.

\section{Mitigation Strategies}

BKSDA and CRU in Aceh Province had done mitigation action to avoid HEC from happening. This included dispelling wild elephants back to their habitat, by using firecracker whose noise would avoid elephants from entering the human settlement. Local communities also helped to make noises, such as firecrackers, bamboo cannons and yell, to prevent elephants from approaching their settlements. CRU is responsible for short-term conflict management, which is not too effective given the fact that the dispelled elephants will come back to the settlements. The addition of CRU is required to deal with short-term conflict management more effectively, as currently there are only 7 CRUs in Aceh Province, while potential areas of HEC occurrence spread all over Aceh Province.

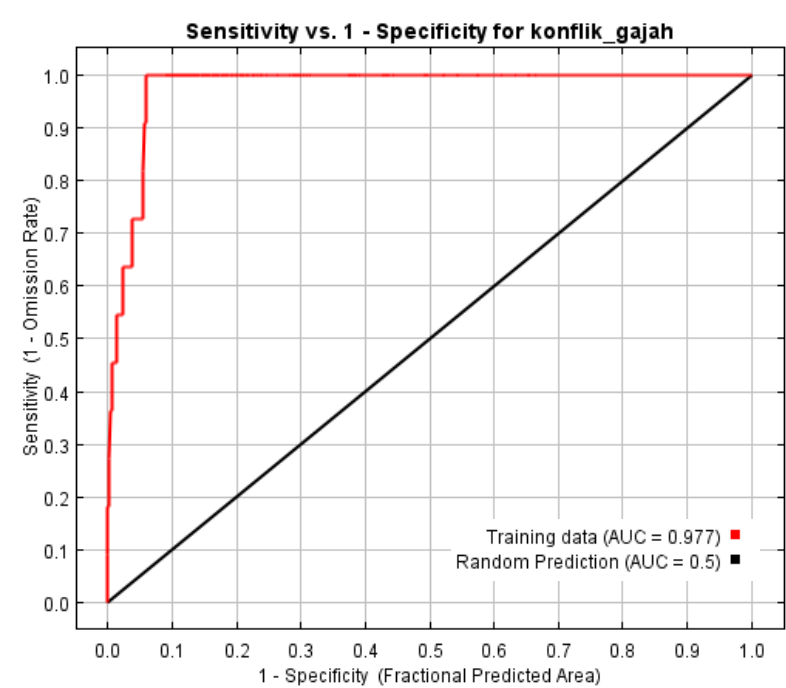

Figure 7. Receiver Operating Characteristic (ROC) curve of HEC data generated from MaxEnt analysis. The closer the graph to the top left corner, the more accurate the test

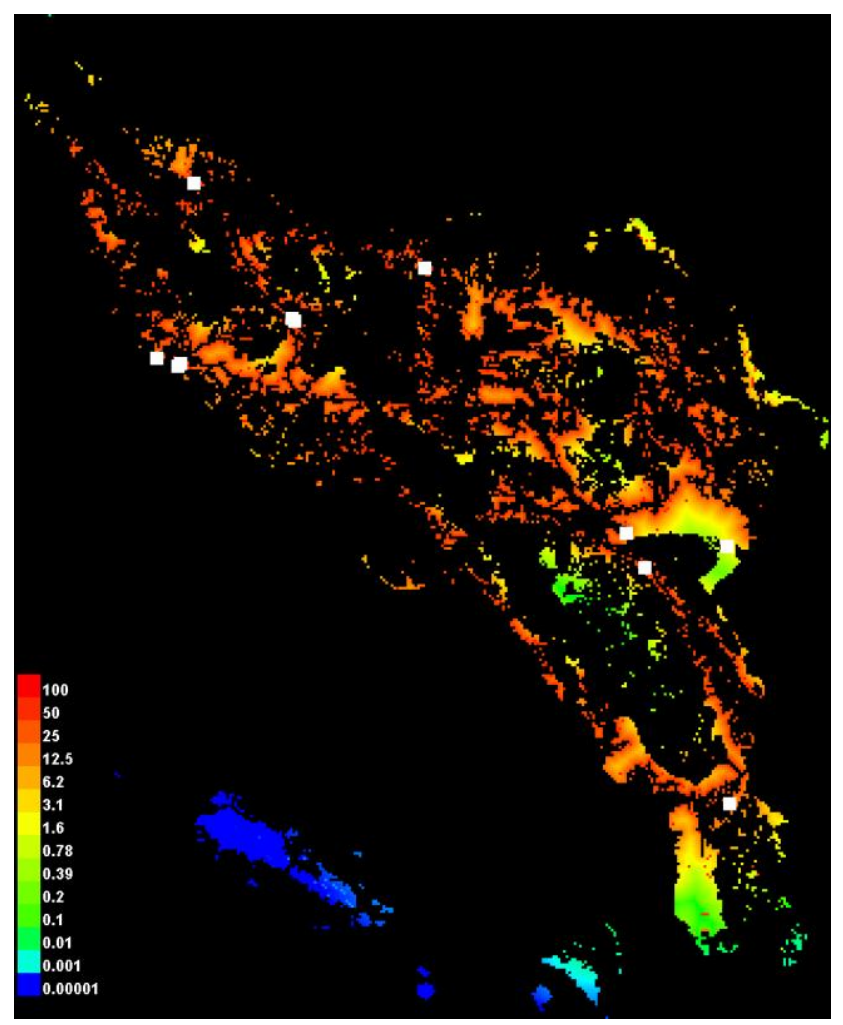

Figure 8. Potential location of Human-elephant Conflict occurrence in Aceh. The legend (left below) showed potential level of HEC occurrence in percent. The higher the number, the more potential the area to HEC occurrence.

Early warning system had also been used to prevent HEC by installing GPS collar around the neck of elephant group leaders and solitary elephants, which were often involved in HEC. GPS collar could detect the position of elephants every three hours or as necessary. This 
technology had made the CRU team became more alert in preparing to dispel when the elephant was seen moving near plantation or settlement areas. Currently, GPS collar had been installed in three elephants in Aceh Utara, Pidie, and Aceh Jaya District. Installation of GPS collar in elephants in Aceh Timur district is also planned to underway since this district is the most HEC-prone district across Aceh Province. Additionally, Aceh Tenggara is going to be the next district whose wild elephant will be installed with GPS collar.

Another mitigation strategy to avoid HEC is to create a ditch barrier, used as a border to human settlement and elephant habitat, in between settlement and forest area. This is to avoid overlapping area used for human activities and areas of elephant movement. Additionally, the planting of elephant's natural grass inside the forest area, which becomes the habitat of elephants, can also prevent the elephants from moving outside the forest for food and water. In Aceh Timur District, at present, there is an ongoing development of ditch barrier in between forest area and cultivated plantation. The construction is planned to create a $48 \mathrm{~km}$ ditch barrier, $6 \mathrm{~km}$ of which has been completed. The ditch is not for HEC prevention purpose only, but it will also help conservation officers to conduct surveillance patrols around the HEC area.

Aceh Governor had issued two decrees related to Human-wildlife Conflict (HWC), Number 522.51/1097/2015 about "the Establishment of Task Force on Conflict Resolution Between Humans and Wildlife", and Number 522.51/1098/2015 about "the Coordination Team for Mitigating Conflict between Humans and Wildlife". These two decrees have shown that the Aceh Government has considered HWC as a serious issue and to tackle it solemnly. Human-wildlife Conflict management should include the analysis of pattern and trend of HWC, as well as underlying causes leading to HWC. Understanding the pattern and trend of HWC will help to anticipate any potential HWC from occurring. This study result suggests that there is a tendency of a rise HEC occurrence during the transitional period of rainy to dry season, and vice versa. This information can be used to increase field patrol frequency during the transitional periods, especially in areas recorded to have the high incidence of HEC.

Moreover, spatial planning at the provincial level (Rencana Tata Ruang Wilayah-Provinsi or RTRWP) should also consider areas with high incidence of HEC as restricted areas for massive development. Figure 8 can potentially be utilized as a basis to find areas 'safe' from HEC for development and to revise the existing provincial spatial planning where massive development is undergoing in areas prone to HEC. Moreover, referring to the study findings that suggest "Distance to settlement" weights the most as an underlying cause of Human-elephant conflict, expansion of residential areas should not occur in areas of elephant habitat. If the expansion cannot be avoided or moved to other places, then mitigation activities such as ditch barrier should be built before the expansion take place, to avoid any potential HEC. Reforestation is also an impactful effort to reduce drastically Human-elephant Conflict, as forest gain will result in more areas for elephant home range and food source. This mitigation strategy can be integrated with Provincial Spatial Planning when designing conservation program in Aceh Province.

\section{ACKNOWLEDGEMENTS}

The authors would like to thank Norway for providing financial support to this research. The authors would also like to thank Head of the Biodiversity Agency of Aceh for the research permit. Many thanks to Conservation Response Unit (CRU) Aceh Jaya, CRU Pidie, CRU Aceh Timur, Gunung Leuser National Park Office, Wildlife Conservation Society, WRI Indonesia colleagues, and anonymous reviewers for their constructive comments.

\section{REFERENCES}

Acharya KP, Paudel PK, Neupane PR, Köhl M. 2016. Human-wildlife conflicts in Nepal: Patterns of human fatalities and injuries caused by large mammals. PLoS ONE 11 (9). DOI: 10.1371/journal.pone.0161717.

Azmi W, Gunaryadi D. 2011. Current Status of Asian Elephants in Indonesia. Gajah 35: 55-61.

Central Bureau of Statistics of Aceh Province. 2017a. Aceh Province in Number, Year 2017. Central Bureau of Statistics of Aceh Province, Banda Aceh. [Indonesian]

Central Bureau of Statistics of Aceh Province. 2017b. Provincial Statictics of Aceh Province 2017. Central Bureau of Statistics of Aceh Province, Banda Aceh. [Indonesian]

Baldwin, RA. 2009. Use of Maximum Entropy Modeling in Wildlife Research. Entropy 11: 854-866.

Berliani K, Alikodra HS, Masy'ud B, Kusrini MD. 2016. Social, economic, cultural and community perception on sumatran elephant (Elephas maximus sumatranus) conflict areas in Aceh Province. Intl J Sci: Basic Appl Res 27 (2): 170-181.

Blouch RA, Simbolon K. 1985. Elephant in Northern Sumatra. IUCN/WWF Project 3033 Report No: 9, Bogor.

Campos-Arceiz A, Blake S. 2011. Megagardeners of the forest - the role of elephants in seed dispersal. Acta Oecologica 37 (6): 542-553.

Chartier L, Zimmermann A, Ladle RJ. 2011. Habitat loss and humanelephant conflict in Assam, India: Does a critical threshold exist? Oryx 45 (4): 528-533.

Directorate General of Forest Protection and Nature Conservation. 2007. The strategies and action plans of elephants conservation in Indonesia. Department of Forestry of Indonesia, Jakarta. [Indonesian]

Directorate General of Forest Protection and Nature Conservation. 2008. Ministerial Decree No. P.48/Menhut-II/2008 concerning Guidelines for Conflict Mitigation between Human and Wild Animals. Department of Forestry of Indonesia, Jakarta. [Indonesian]

Dublin, HT, Hoare RE. 2004. Searching for solutions: The evolution of an integrated approach to understanding and mitigating human-elephant conflict in Africa. Hum Dimens Wild1 9 (4): 271-278.

Gopala A, Hadian O, Sunarto, Sitompul A, Williams A, Leimgruber P, Chambliss SE, Gunaryadi D. 2011. Elephas maximus ssp. sumatranus. The IUCN Red List of Threatened Species 2011: e.T199856A9129626. DOI: 10.2305/IUCN.UK.20112.RLTS.T199856A9129626.en. [28 November 2018].

Grehenson G. 2015. Sumatran elephants are infected by herpes. of Gadjah Mada University, Yogyakarta.

Gunaryadi D, Sugiyo, Hedges S. 2017. Community-based human-elephant conflict mitigation: The value of an evidence-based approach in promoting the uptake of effective methods. PloS One 12 (5). DOI: 10.1371/journal.pone.0173742.

Hedges S, Tyson MJ, Sitompul AF, Kinnaird MF, Gunaryadi D, Aslan. 2005. Distribution, status, and conservation needs of Asian elephants (Elephas maximus) in Lampung Province, Sumatra, Indonesia. Biol Conserv 124 (1): 35-48.

Hoare R. 2000. African elephants and humans in conflict: The outlook for co-existence. Oryx 34 (1): 34-38. 
Hoare RE, Du Toit JT. 1999. Coexistence between people and elephants in African savannas. Conserv Biol 13 (3): 633-639.

Inskip C, Zimmermann A. 2009. Human-felid conflict: A review of patterns and priorities worldwide. Oryx 43 (1): 18-34.

Kerley LL, Goodrich JM, Miquelle DG, Smirnov EN, Quigley HB, Hornocker MG. 2002. Effects of roads and human disturbance on Amur tigers. Conserv Biol 16 (1): 97-108.

Keumala H. 2018. Only 500 individuals of Sumatran elephant left in Aceh. Aceh Trend Mediana. http://www.acehtrend.com/2018/02/19/populasi-gajah-sumatera-diaceh-hanya-tersisa-500-ekor/ [Indonesian]

Kuswanda W, Barus SP. 2017. The biodiversity and determination of "umbrella species" of wildlife in Gunung Leuser National Park. Jurnal Penelitian Kehutanan Wallacea 6 (2): 113-123. [Indonesian]

Linkie M, Chapron G, Martyr DJ, Holden J, Leader-Williams N. 2006. Assessing the viability of tiger subpopulations in a fragmented landscape. J Appl Ecol 43 (3): 576-586

Mattson DJ, Herrero S, Wright RG, Pease CM. 1996. Science and management of rocky mountain grizzly bears. Conserv Biol 10 (4): 1013-1025.

Nyhus PJ, Sumianto, Tilson R. 2000. Crop-raiding elephants and conservation implications at Way Kambas National Park, Sumatra Indonesia. Oryx 34 (4): 262-274.
Perera BMAO. 2009. The human-elephant conflict: A review of current status and mitigation methods. Gajah 30: 41-52.

Primm SA. 1996. A pragmatic approach to grizzly bear conservation. Conserv Biol 10 (4): 1026-1035.

Rood EJJ, Azmi W, Linkie M. 2008. Elephant crop raiding in a disturbed environment: The effect of landscape clearing on elephant distribution and crop raiding patterns in the North of Aceh, Indonesia. Gajah 29: 17-23.

Santiapillai C, Ramono WS. 1990. Sumatran Elephant Database: A Preliminary Report. WWF and Directorate of Forest Protection and Nature Conservation, Bogor.

Sitompul AF, Tyson MJ, Caroll JP, O’Brien T. 2010. Crop raiding by elephants adjacent to two national parks in Lampung Province, Sumatra, Indonesia. Gajah 33: 26-34.

Sukumar R. 2006. A brief review of the status, distribution and biology of wild Asian elephants Elephas maximus. Intl Zoo 40: 1-8.

Swets JA. 1988. Measuring the accuracy of diagnostic systems. Science 240: $1285-1293$.

Wibisono HT, Pusparini W. 2010. Sumatran tiger (Panthera tigris sumatrae): A review of conservation status. Integr Zool 5 (4): 313 323.

Zoological Society of London. 2011. A Practical Handbook for Conserving High Conservation Value Species and Habitats within Oil Palm Landscapes. ZSL Indonesia, Bogor. 